Загорка О. М., д-р військ. наук, професор

(0000-0003-1131-0904)

Бойко В. О., канд. екон. наук, ст. наук. співроб.

(0000-0002-3264-7111)

Загорка I. O.

(0000-0002-0693-1434)

Центр воєнно-стратегічних досліджень Національного університету оборони України імені Івана Черняховського, Київ

\title{
Обгрунтування бойового складу угруповання військ для відбиття агресії
}

Резюме. На підставі двоетапного застосування методу таксономії розроблено методику, що дає змогу більш повно врахувати можливі способи бойових дій військ противника і своїх військ, та забезпечити збалансованість родів військ під час визначення бойового складу угруповання військ для відбиття агресії.

Ключові слова: угруповання військ; бойовий склад; збалансованість; способи бойових дій; метод таксономії; планування експерименту.

Постановка проблеми. Визначення бойового складу угруповання військ $є$ одним 3 важливих завдань, яке має виконуватися органами військового управління (ОВУ) під час створення угруповання військ для відбиття агресії та планування розвитку (реформування) збройних сил на визначений період. Вирішення цієї проблеми набуває особливої актуальності через воєннополітичну обстановку, яка складається навколо України, та у зв'язку 3 подіями останніх років на сході країни. Це потребує перегляду підходів до забезпечення воєнної безпеки держави.

На теперішній час у Збройних Силах (3С) України проводяться заходи щодо підвищення їх боєздатності, створюються нові військові формування, удосконалюються організаційно-штатні структури військових формувань. В умовах наявності загроз у воєнній сфері та суттєвих ресурсних обмежень проблема визначення раціонального бойового складу угруповання військ для відбиття агресії має як наукову, так і практичну значущість.

Аналіз останніх досліджень i публікацій. Методичні положення обгрунтування складу 3С наведені у працях [1, 2].

У праці [1] тільки фрагментарно розглянуто методичний підхід до обгрунтування бойового складу угруповання військ для відбиття агресії. Бойовий склад угруповання військ у праці [2] пропонується визначати 3 використанням однокритеріального методу оцінювання, що не дає змоги визначати його збалансований бойовий склад за видами ЗС і родами військ
[3]. У праці [4] розглянути методичні положення визначення доцільного способу бойових дій угруповання військ в операції (застосовуються методи теорії ігор) та його раціонального бойового складу (застосовується метод таксономіі). Однак ці методичні положення не можуть повною мірою забезпечити визначення збалансованого бойового складу угруповання військ 3 урахуванням можливих способів бойових дій військ противника.

Мета статті полягає в удосконаленні методичних положень обгрунтування бойового складу угруповання військ для відбиття агресії.

Виклад основного матеріалу. Відповідно до принципів системного підходу угруповання військ розглядається як складна організаційно-технічна система, яка поділяється на підсистеми (рис. 1).

Ударна підсистема $\epsilon$ основою угруповання військ, оскільки іiі склад (бойові сили і засоби) визначає спроможність відбиття агресії. Саме методичні положення визначення бойового складу ударної підсистеми угруповання військ розглядаються надалі.

Склад інших підсистем угруповання військ може визначатися нормативно 3 урахуванням попереднього досвіду створення угруповань військ.

Ударну підсистему угруповання військ утворюють бойові сили i засоби, які відповідають родам військ видів ЗС. Підрозділи цих родів військ уважаються параметрами ударної підсистеми угруповання військ. 


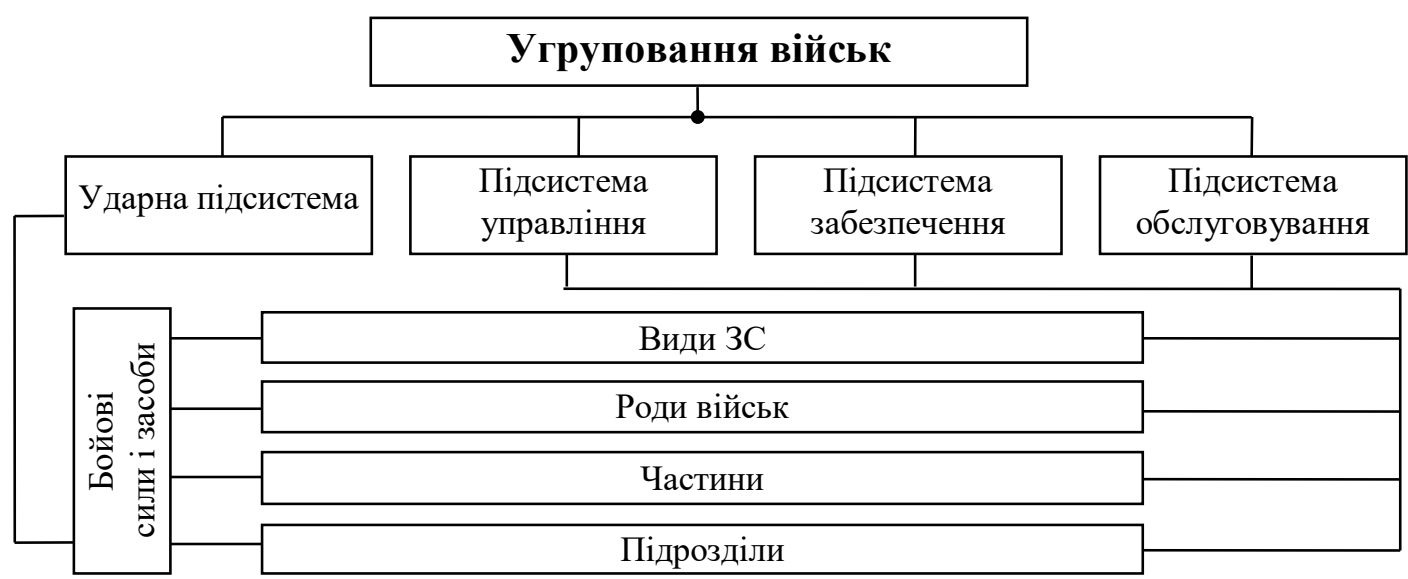

Рис. 1. Структура угруповання військ як складна організаційно-технічна система

Відповідно до методичних положень, що викладені у працях [1-4], для обгрунтування бойового складу угруповання військ формується множина варіантів цього складу та 3 них обирається найкращий. Такий підхід доцільно застосовувати і під час удосконалення методичних положень обгрунтування бойового складу угруповання військ для відбиття агресії.

Для виконання мети дослідження необхідно:

розробити структурну схему методики обгрунтування бойового складу угруповання військ для відбиття агресії;

визначити порядок урахування можливих способів бойових дій угруповань військ противника і своїх військ в операції (під час ведення бойових дій);

уточнити порядок формування варіантів бойового складу угруповання військ;

удосконалити методичні положення визначення раціонального бойового складу угруповання військ для відбиття агресії.

Структурна схема методики обгрунтування бойового складу угруповання військ для відбиття агресії наведена на рис. 2.

У методиці, насамперед, визначаються завдання угруповання військ, можливі способи бойових дій військ противника i наших військ у воєнному конфлікті. У процесі визначення способів бойових дій військ противника ураховується мета розв'язання воєнного конфлікту, склад угруповання військ противника i форма його застосування. Для протидії противнику призначається базовий (початковий) склад угруповання наших військ i визначаються адекватні форма і способи бойових дій в операції (під час ведення бойових дій).

$$
\begin{aligned}
& \text { Найбільш } \\
& \text { показниками оцінювання ефективності } \\
& \text { застосування військ є втрати сторін в операції } \\
& \text { (під час ведення бойових дій). Тому вимоги до } \\
& \text { ефективності застосування угруповання військ } \\
& \text { пропонується задавати критерієм, який } \\
& \text { визначається співвідношенням } \\
& \qquad W_{\text {nотр }}=\frac{\delta_{\text {np потр }}}{\delta_{\text {нвдоn }}} ; \delta_{\text {нвдо }}>0,(1) \\
& \text { де } \delta_{\text {np потр }}-\text { математичне сподівання }
\end{aligned}
$$
величини відносних втрат, яких потрібно завдати військам противника;

$$
\delta_{\text {нвдо }} \text { - математичне сподівання величини }
$$
відносних втрат, які допускаються для угруповання наших військ.

У методиці визначення раціонального бойового складу угруповання військ здійснюється на підставі порівняння його варіантів. Така задача належить до задач багатокретіального аналізу [4]. Під час іiі розв'язання доцільно ураховувати такі показники:

математичне сподівання величини відносних втрат, яких завдають противнику наші війська в операції (під час ведення бойових дій);

математичне сподівання величини відносних втрат, яких завдає противник нашим військам;

внески родів військ (параметри ударної підсистеми) у загальні втрати військ противника; математичні сподівання величин відносних втрат родів наших військ; вартість озброєння угруповання наших військ; вартість озброєння родів військ. 
ВОСННА СТРАТЕГІЯ

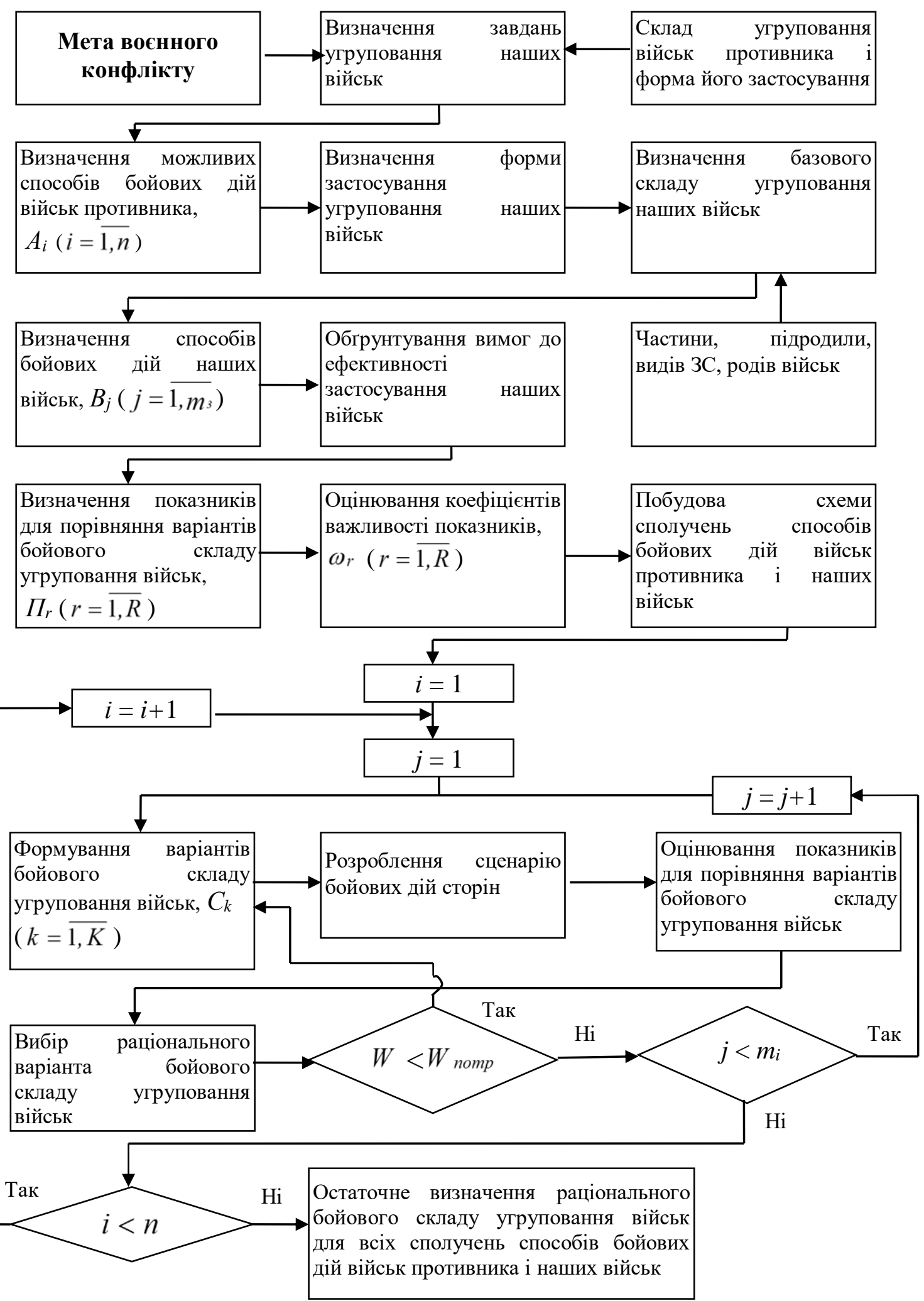

Рис. 2. Структурна схема методики обгрунтування бойового складу угруповання військ для відбиття агресії

Для оцінювання важливості показників можна використовувати експертний метод ранжирування $[5,6]$, який часто застосовується і не потребує подальших пояснень.

Визначення бойового складу угруповання військ здійснюється для можливих способів бойових дій військ противника і наших військ. Кожному способу бойових дій військ противника протиставляється декілька способів бойових дій наших військ.

Схема сполучень способів бойових дій військ противника і наших військ наведена на рис. 3. 


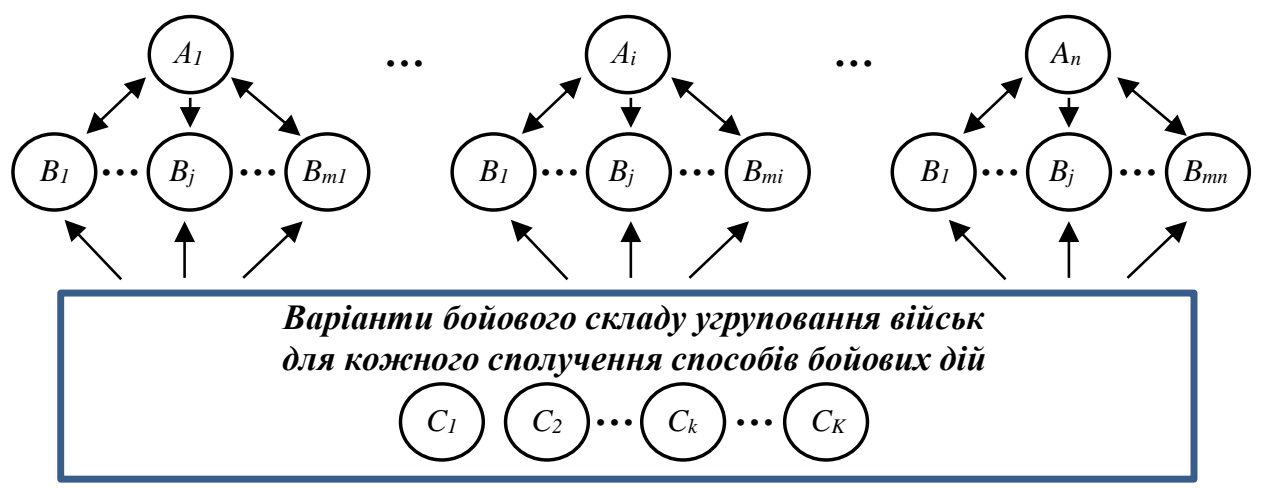

Рис. 3. Схема сполучень способів бойових дій військ противника і наших військ

На відміну від методики, викладеної у праці [4], у якій бойовий склад угруповання військ визначається для найбільш імовірних способів бойових дій сторін, пропонується під час розв'язання цієї задачі враховувати всі способи бойових дій військ противника i наших військ як показано на рис. 3 .

Відповідно до схеми методики (див. рис. 2) формування варіантів бойового складу угруповання військ здійснюється для кожного сполучення способів бойових дій військ противника і наших військ.

Для цього застосовується метод планування експерименту [7]. План експерименту складається за допомогою варіювання параметрів ударної підсистеми. До таких параметрів можуть, наприклад, належати [4]: склад механізованих, танкових, аеромобільних військ, ракетних військ i артилерії, зенітних ракетних військ, тактичної авіації. Склад решти родів військ може залишатися незмінним. Рівні варіювання параметрів ударної підсистеми встановлюються 3 урахуванням обмежень на склад родів військ. Варіювання параметрів здійснюється відносно їх початкового значення. За одиниці варіювання параметрів бойового складу угруповання військ доцільно прийняти: батальйон, дивізіон, батарея, ескадрилья.

У праці [8] рекомендується при кількості параметрів, що варіюються, до чотирьох використовувати повний факторний експеримент, а більше чотирьох - дрібне факторне планування. Звичайно варіювання параметрів під час розв'язання подібних задач здійснюється на трьох рівнях. Готові плани експериментів наведені у праці [9]. Для трьох параметрів план обчислювального експерименту містить 10 , чотирьох - 15 , п'яти - 21, шести - 28, семи - 37 спроб (варіантів).

Відповідно до розробленого сценарію для кожного варіанта бойового складу угруповання військ оцінюються показники, за якими здійснюється їх порівняння (вибір раціонального варіанта).

Задача визначення раціонального бойового складу угруповання військ за сутністю $\epsilon$ задачею синтезу ударної підсистеми. Відповідно до праці [10] під раціональним розуміється збалансований склад параметрів (родів військ) угруповання військ, який забезпечує потрібний рівень ефективності його застосування за мінімальних витратах (втратах) сил і засобів. Збалансованість бойового складу угруповання військ - це взаємна відповідність якісного та кількісного складу родів військ для виконання усього діапазону завдань, що покладаються на угруповання військ в операції (під час ведення бойових дій).

У методиці під час розв'язання задачі визначення раціонального бойового складу угруповання військ для кожного сполучення способів бойових дій військ противника i наших військ, як i у працях [3, 4], використовується метод таксономії [11].

Під час порівняння варіантів бойового складу угруповання військ використовується таксономічна відстань, яка визначається за правилами аналітичної геометрії. Усі показники поділяються на стимулятори i дестимулятори. У нашому випадку показники, збільшення яких сприяє ефективності виконання завдань угрупованням військ (втрати противника) вважаються стимуляторами, а навпаки - дестимуляторами (втрати своїх військ), зокрема вартість озброєння. Варіанти порівнюються 3 еталонним варіантом, якому відповідають максимальні значення показниківстимуляторів i мінімальні значення показників-дестимуляторів.

Вихідними даними для застосування методу таксономії $€$ матриця значень показників

$$
\left\|x_{r k}\right\|, \quad(r=\overline{1, R}, \quad k=\overline{1, K}), \text { вигляд якої }
$$
наведено у Табл. 1. 
Значення показників для порівняння варіантів бойового складу угруповання військ

\begin{tabular}{|c|c|c|c|c|c|c|}
\hline \multirow{2}{*}{ Показник } & \multicolumn{7}{|c|}{ Варіант бойового складу } & $C_{K}$ \\
\cline { 2 - 7 } & $C_{1}$ & $C_{2}$ & $\cdots$ & $C_{k}$ & $\ldots$ & $x_{1 K}$ \\
\hline $\boldsymbol{\Pi}_{\mathbf{1}}$ & $x_{11}$ & $x_{12}$ & $\cdots$ & $x_{2 k}$ & $\ldots$ & $x_{2 K}$ \\
\hline $\boldsymbol{\Pi}_{\mathbf{2}}$ & $x_{21}$ & $x_{22}$ & $\ldots$ & $x_{r k}$ & $\ldots$ & $x_{r K}$ \\
\hline $\boldsymbol{\Pi}_{\boldsymbol{r}}$ & $x_{r 1}$ & $x_{r 2}$ & $\ldots$ & $x_{R k}$ & $\ldots$ & $x_{R K}$ \\
\hline $\boldsymbol{\Pi}_{\boldsymbol{R}}$ & $x_{R 1}$ & $x_{R 2}$ & $\ldots$ & $\ldots$ & $\ldots$ & $\ldots$ \\
\hline
\end{tabular}

Оскільки елементи матриці можуть мати різні одиниці вимірювання, вони приводяться до стандартизованого вигляду за формулою

$$
z_{r k}=w_{r} \cdot \frac{x_{r k}-\overline{x_{r}}}{\sigma_{r}},
$$

де $\overline{x_{r}}, \sigma_{r}$ - математичне сподівання і середнє квадратичне відхилення $r$-го показника відповідно;

$w_{r} \quad-\quad$ коефіцієнт важливості $r$-го показника.

Для еталонного бойового складу угруповання військ $z_{10}, z_{20}, \ldots, z_{r 0}, \ldots, z_{R 0}$ показники визначаються таким чином:

$$
z_{r 0}=\left\{\begin{array}{c}
\max \mathrm{z}_{r k}, r \in S \\
r \\
\min _{r} \mathrm{z}_{r k}, r \in D_{s}
\end{array}\right\},
$$

де $S, D_{s}$ - сукупність показників-стимуляторів i показників-дестимуляторів відповідно.

Таксономічні відстані обчислюються за формулою

$$
\gamma_{k 0}=\left[\sum_{r}\left(z_{r k}-z_{r 0}\right)^{2}\right]^{1 / 2} ; k=\overline{1, K} ; r=\overline{1, R}
$$

Таксономічний показник $\beta_{k}$ розраховується таким чином:

$\overline{\gamma_{0}}=\frac{1}{K} \sum_{k} \gamma_{k 0} ; \alpha_{0}=\left[\frac{1}{K}\left(\gamma_{k 0}-\gamma_{0}\right)^{2}\right]^{1 / 2} ; \gamma_{0}=\overline{\gamma_{0}}+2 \alpha_{\mathrm{p}}$

Для кожного сполучення способів бойових дій військ противника і наших військ раціональним вважається варіант бойового складу угруповання військ, якому відповідає максимальне значення таксономічного показника $\beta_{k}$.

Відповідно до методики (див. рис. 2), коли ефективність застосування угруповання військ обраного складу $W$ менше потрібної
$W_{\text {nотр }}$, здійснюється корегування варіантів бойового складу і розрахунки повторюються.

Раціональні варіанти бойового складу угруповання військ визначаються для $L$ сполучень способів бойових дій військ противника і наших військ

$$
L=\sum_{i} m_{i}, i=\overline{1, n} \quad m_{i}
$$

Кожному раціональному варіанту бойового складу угруповання військ відповідають певні значення його параметрів (кількість підрозділів родів військ) $a_{s l}, s=\overline{1, S}$ , $l=\overline{1, L}$, де $S$-кількість параметрів ударної підсистеми, що досліджується.

Якщо визначені максимальні значення параметрів $\max _{l} a_{s l}$, то такий бойовий склад угруповання військ може забезпечити виконання завдань при будь-якому сполученні способів бойових дій військ противника i наших військ. Однак такий бойовий склад $\epsilon$ зайво збільшеним i не може бути збалансованим.

Параметри бойового складу угруповання військ (ударної підсистеми) також можуть визначатися як середнє значення $a_{s}^{*}=\frac{1}{L} \sum_{l} a_{s l}$, що також не забезпечує збалансованість родів військ. $\alpha_{\text {paц }} \beta_{k \text { нальноғо }}=$ Воднчас пойового складу угруповання військ для кожного сполучення способів бойових дій військ противника і своїх військ було оцінено відповідні показники. Це дає змогу для визначення збалансованого бойового складу угруповання військ також використати метод таксономії. У цьому випадку кількість варіантів бойового складу угруповання військ дорівнює $L$. Таким чином у методиці, що розроблена, для визначення збалансованого бойового складу угруповання військ застосовано двоетапне використання методу таксономії.

Висновок. Угруповання військ під час удосконалення методичних положень 
обгрунтування його бойового складу розглядається як складна організаційнотехнічна система, основним структурним елементом якої є ударна підсистема. Саме для визначення збалансованого складу бойових сил і засобів ударної підсистеми призначена розроблена методика. У методиці, на відміну від існуючих підходів для визначення збалансованого бойового складу угруповання військ для відбиття агресії, застосовано двоетапне використання методу таксономії.

Розроблені методичні положення надалі доцільно використати під час створення спеціального математичного програмного забезпечення ОВУ.

\section{СПИСОК ВИКОРИСТАНОЇ ЛІТЕРАТУРИ}

1. Тимошенко Р. I., Загорка О. М. З Загальні методологічні положення воєнно-економічного обгрунтування складу Збройних Сил України на сучасному етапі їх реформування. Наука і оборона. 2014. № 1. С. 43-48.

2. Основы теории и методологии планирования строительства вооруженных сил Российской Федерации : военно-теоретический труд / под общ. ред. А. В. Квашнина. Москва : Воентехиздат, 2002. $232 \mathrm{c}$.

3. Методичний підхід до визначення бойового складу Збройних Сил воєнного i мирного часу / О. М. Загорка, В. С. Фролов, В. М. Можаровський,
I. О. Загорка // Збірник наукових праць Центру воєнно-стратегічних досліджень Національного університету оборони України імені Івана Черняховського. Київ, 2019. № 1 (65). С. 6-11.

4. Можаровський В. М., Загорка О. М. Основні положення методики визначення варіанта (способу) бойових дій та складу угруповання військ (сил) для відбиття агресії. Наука і оборона. 2011. № 1. С. 3-6.

5. Бешелев С. Д., Гурвич Ф.Г. Экспертные оценки. Москва : Наука, 1973. 160 с.

6. Денисов А. А. Теория больших систем управления : уч. пособ. для вузов / А. А. Денисов, Д. Н. Колесников. Ленинград : Энергоиздат, 1982. $288 \mathrm{c}$.

7. Барабащук В. И., Креденцер Б. П., Мирошниченко В. И. Планирование эксперимента в технике / под общ. ред. Б. П. Креденцера. Киев : Техника, 1989. $200 \mathrm{c}$.

8. Ашмарин И. П., Васильев Н. Н., Амбросов В. А. Быстрые методы статистической обработки и планирование экспериментов. Ленинград : Ленингр. университет, 1974. 76 с.

9. Таблицы планов эксперимента для факторных и полиномиальных моделей / В. З. Бродский и др. Москва : Металлургия, 1982. 350 с.

10. Загорка О. М., Мосов С. П., Сбітнєв А. І., Стужук П. І. Елементи дослідження складних систем військового призначення : навч. посіб. Київ : HAOУ, 2005. $100 \mathrm{c}$.

11. Плюта В. Сравнительный многомерный анализ в эконометрическом моделировании. Москва : Финансы и статистика, 1989. 176 с.

\section{Стаття надійшла до редакційної колегії 21.03.2021}

\section{Annotation}

A major task which decides the organs of military management during creation of grouping of troops for the reflection of aggression is determination of her rational composition. The methods of ground of battle composition of grouping of troops, which is based on the use of method of taxonomy, are offered in the article.

The grouping of troops is examined as a difficult organizationally-technical system, her basis is a shock subsystem which contains combatant forces and facilities of births of troops of types of Military Powers. Exactly for determination of her composition methods are intended.

Determination of battle composition of shock subsystem is carried out for the possible methods of battle actions of troops of opponent and troops. Thus every method of battle actions of troops of opponent a few methods of battle actions of our troops are matched against. For every method of battle actions of our troops with the use of method of planning of experiments the variants of battle composition of shock subsystem of grouping of our troops are formed.

The rational variant of battle composition of shock subsystem is determined for every method of battle actions of grouping of our troops with the use of method of taxonomy on indexes which characterize efficiency of his application and cost of armament. At a decision tasks are taken into account only variants of battle composition of shock subsystem, at which efficiency of application of grouping of troops is provided not below than necessary.

In second times the method of taxonomy is used for the choice of the best (balanced) variant of battle composition from rational variants which were certain for every method of battle actions of grouping of troops. A twostage use of method of taxonomy allows most reasonably to determine battle composition of grouping of troops taking into account the possible methods of battle actions of troops of opponent.

The brought methods over can be used by the organs of military management during determination of battle composition of grouping of troops for the reflection of aggression.

Keywords: grouping of troops; battle composition; balanced; methods of battle actions; method of taxonomy; planning of experiment. 